\title{
Insulin treatment prevents diabetes mellitus but not thyroiditis in RT6-depleted diabetes resistant $\mathrm{BB} /$ Wor rats
}

\author{
P.A.Gottlieb ${ }^{1}$, E.S.Handler ${ }^{1}$, M.C.Appel ${ }^{2}$, D.L. Greiner ${ }^{3}$, J.P. Mordes ${ }^{1}$ and A.A. Rossini ${ }^{1}$ \\ Departments of ${ }^{1}$ Medicine and ${ }^{2}$ Pathology, University of Massachusetts Medical School, Worcester, Massachusetts and the \\ ${ }^{3}$ Department of Pathology, University of Connecticut Health Center, Farmington, Connecticut, USA
}

Summary. Prophylactic insulin administration is known to prevent hyperglycaemia in diabetes prone $\mathrm{BB}$ rats and nonobese diabetic mice. This study investigated the effect of insulin treatment on the development of overt diabetes, clinically inapparent anti-islet autoreactivity, and thyroiditis in RT6-depleted diabetes resistant BB rats. Fewer than $1 \%$ of these animals develop spontaneous diabetes, but if depleted of $\mathrm{RT}^{+}{ }^{+} \mathrm{T}$ cells $>50 \%$ become hyperglycaemic. We treated 30-day-old diabetes resistant rats with anti-RT6.1 monoclonal antibody, exogenous insulin, or both. Up to 60 days of age, 16 of 20 rats given antibody alone became diabetic, compared with 1 of 20 also treated with antibody plus insulin. Up to 110 days of age, only 1 of 10 rats treated with both insulin and antibody between 30 and 60 days became diabetic. Histologic study of non-diabetic insulin plus anti-RT6 antibody treated rats revealed insulitis in 3 of 9 at 60 days old, and in sulitis in 3 of 8 and thyroiditis in 6 of 7 at 110 days of age. Nondiabetic animals were also found to harbour autoreactive spleen cells that adoptively transferred diabetes. Splenocytes from 60 or 110-day-old non-diabetic donors that had been treated with insulin and antibody between 30 and 60 days of age induced diabetes in 7 of 13 and 6 of 8 adoptive recipients respectively. We conclude that insulin treatment prevents clinical diabetes in the RT6-depleted diabetes resistant BB rat, but this treatment does not prevent the development of autoreactive cell populations that cause thyroiditis and adoptively transfer diabetes.

Key words: BB rat, insulitis, insulin treatment, RT6, adoptive transfer, thyroiditis.
Injections of insulin prevent autoimmune diabetes mellitus in the diabetes prone (DP) BB rat [1-3] and the nonobese diabetic (NOD) mouse [4]. In humans, intensive insulin therapy of Type 1 (insulin-dependent) diabetic children helps preserve residual Beta-cell function [5], and clinical trials of low-dose insulin prophylaxis of prediabetic subjects have been announced [6]. The present study investigated the effects of insulin treatment on the development of clinical diabetes, clinically inapparent autoreactivity, and thyroiditis in a third animal model of Type 1 diabetes, the RT6-depleted diabetes resistant (DR) BB rat.

DR BB rats were derived by selective breeding from DP forebears [7]. Spontaneous diabetes and thyroiditis occur in $<1 \%$ of DR rats, compared with $>50 \%$ of DP rats. Unlike the DP, the DR are not lymphopoenic and circulate normal numbers of T cells of the RT6.1 phenotype [8]. RT6 is a maturational T-cell alloantigen expressed on $\sim 60 \%$ of $\mathrm{T}$ cells in the rat [9]. It exists in two allelic forms, vis RT6.1 and RT6.2. In vivo depletion of RT6.1 ${ }^{+}$T cells by administration of a cytotoxic monoclonal antibody (mAb) to 30-day-old $\mathrm{DR} \mathrm{BB} /$ Wor rats induces diabetes
[8] and thyroiditis [10] in $>50 \%$ of treated animals by 60 days of age. Mitogen-activated spleen cells from both diabetic and non-diabetic RT6-depleted DR rats adoptively transfer the disease [8].

In the present study, we used these animal resources to pose three questions. Can exogenous insulin treatment prevent diabetes in RT6-depleted DR rats? Can exogenous insulin treatment prevent thyroiditis in these rats? Are spleen cells of non-diabetic RT6-depleted DR rats still capable of adoptively transferring diabetes after prophylactic insulin injections?

\section{Materials and methods}

\section{Animals}

DP and DR BB/Wor rats were obtained from the specific pathogen free colony maintained at the University of Massachusetts, Worcester under the auspices of the National Institutes of Health $[7,11,12]$. At the time of these experiments, the cumulative incidence of DP diabetes averaged $\sim 60 \%$ in both sexes. Most cases $(>85 \%$ ) oc- 
curred between 60 and 120 days of age; $<0.5 \%$ occurred before 60 days of age. The DR BB/Wor rats used in these studies were from the "WA" subline and were at least the 30 th generation of inbreeding [7].

It is now known that exposure to environmental pathogens affects the incidence of spontaneous diabetes in DP BB/Wor rats [11] and both spontaneous and RT6-depletion diabetes in the DR $\mathrm{BB} /$ Wor rat [12]. In the present study animals obtained from the specific pathogen free facility were subsequently housed in conventional quarters that maintain a high standard of cleanliness but do not provide sterilized food, water, or bedding. At the time these experiments were performed, commercial serological study of sentinel rats (Charles River Laboratories, Wilmington, Mass., USA) housed together with our experimental animals indicated the presence of sendai virus, Kilham's rat virus (KRV), Toolan's $\mathrm{H}-1$ virus ( $\mathrm{H}-1)$, and sialodacryoadenitis virus (SDA), but absence of Mycoplasma pulmonis, pneumonia virus of mice (PMV), lymphocytic choriomeningitis virus (LCMV), mouse adenovirus (MAD), Theiler's murine encephalomyelitis virus (GD-VII), and reovirus type 3 (REO3).

All BB rats express the RT $1{ }^{u}$ MHC haplotype; DR rat T cells express the RT6.1 antigen; DP rats have few, if any, RT6 ${ }^{+}$lymphocytes [13]. Animals were housed under standard laboratory conditions and maintained in accordance with National Institutes of Health recommendations [14]. Plasma glucose was measured with a Beckman II glucose analyser (Beckman, Fullerton, Calif., USA). Animals were weighed and urine tested for glucose (Test-Tape, Eli Lilly, Indianapolis, Ind., USA) three times per week. Two successive daily plasma glucose determinations $\geq 11.1 \mathrm{mmol} / 1$ defined diabetes in glycosuric animals.

\section{Reagents and injection protocols}

DS4.23 anti-RT6.1 monoclonal antibody was prepared using ratmouse hybridomas grown for $72 \mathrm{~h}$ in serum-free RPMI-1640 (Gibco, Grand Island, NY, USA) containing 1\% Nutridoma-SP (Boehringer Mannheim Biochemicals, Indianapolis, Ind., USA). To deplete DR rats of $\mathrm{RT}^{*}{ }^{+} \mathrm{T}$ cells, unconcentrated hybridoma supernatant was injected intraperitoneally at a dose of $2 \mathrm{ml} / \mathrm{rat}$ into 30 -day-old DR rats five times per week up to 60 days of age. Previous studies have documented that this procedure results predominantly in cellular elimination and does not modulate the RT6 protein [15].

Insulin-treated rats received daily subcutaneous injections of U-40 PZI pork insulin (Eli Lilly) at a dose of $1.5-2.0 \mathrm{U} / 100 \mathrm{~g}$ body weight. Plasma glucose concentrations were measured $16-20 \mathrm{~h}$ after insulin administration to assess the degree of hypoglycæmia.

\section{Immunophenotypic analyses}

Cervical lymph nodes resected under Metofane anaesthesia (Pitman-Moore, Washington Crossing, NJ, USA) were used to quantify the depletion of RT6. + $^{+}$T cells during antibody treatment and to document their reappearance after injections were discontinued. Lymph node cells were prepared as previously described and stained with either DS4.23 anti-RT6.1 mAb [8] or 6A5 anti-RT6.2 mAb [16] followed by goat anti-mouse IgG. The number of RT6.1 cells was determined by subtracting the number of cells staining positively for RT6.2 from the number staining for RT6.1.

\section{Adoptive transfer of mitogen-activated spleen cells}

Spleens were removed aseptically and extruded through a cell sieve. Splenocytes were cultured for $72 \mathrm{~h}$ in RPMI-1640, containing $5 \mu \mathrm{g} / \mathrm{ml}$ concanavalin A (Miles-Yeda, Rehovot, Israel), $10 \%$ heat inactivated fetal bovine serum, $5 \mathrm{mmol} / 1 \mathrm{~L}$-glutamine, $5 \times 10^{-5} \mathrm{~mol} / 12$ mercaptoethanol, and penicillin $(400 \mathrm{IU} / \mathrm{ml})$. Cells were then washed, suspended in RPMI, adjusted to a concentration of $40 \times 10^{6}$ cells, and injected into 30 -day-old DP recipients. These animals were tested for diabetes up to 60 days of age. Since the frequency of diabetes among DP rats before 30 days of age is $<0.5 \%$, the appearance of hyperglycaemia in these animals is interpreted as evidence of the adoptive transfer of the disease [17].

\section{Experimental design}

Littermate 30-day-old DR rats were randomized into three treatment groups that were injected with anti-RT6.1 antibody, insulin, or both until the onset of diabetes or up to 60 days of age. At 60 days of age some of the non-diabetic animals in each group were killed one day after their last treatment for histological study and to obtain spleen cells for adoptive transfer. A group of five separate untreated DR rats were used to provide histologic controls. All treatment of the remaining non-diabetic animals in each group was stopped at 60 days of age, and the rats were monitored for diabetes until 110 days of age to determine if insulin prophylaxis had delayed rather than prevented diabetes. At 110 days, all non-diabetic animals were killed to obtain histologic specimens and spleen cells for adoptive transfer.

Pancreas and thyroid samples for histology were fixed in Bouin's solution and prepared for routine haematoxylin and eosin light microscopy. Insulitis and thyroiditis were recorded as present or absent, without regard to the severity of the lesions. Pancreatic insulin and glucagon reserves were studied using immunoperoxidase histochemistry as previously described [18].

\section{Statistical analysis}

Parametric data are presented as means \pm SEM and were compared by analysis of variance with the least significant difference procedure for a posteriori contrast [19]. Non-parametric data were analysed by using $c h i^{2}$ and Fisher exact statistics [20].

\section{Results}

The frequency of diabetes and insulitis among DR rats treated with insulin, anti-RT6 monoclonal antibody, or both, between 30 and 60 days of age is shown in Table 1 . Depletion of RT6 ${ }^{+} \mathrm{T}$ cells induced diabetes in most DR rats. Co-administration of insulin prevented nearly all cases of diabetes, but did not prevent insulitis. Rats given insulin alone developed neither diabetes nor insulitis. Body weight gain did not differ among the three treatment groups (data not shown). The average plasma glucose concentrations were $5.2 \pm 0.6 \mathrm{mmol} / \mathrm{l}(n=17 \mathrm{sam}$ ples) in rats treated with insulin alone, $4.7 \pm 0.4 \mathrm{mmol} / 1$ $(n=22$ samples) in rats given both insulin and anti-RT6 antibody, and $7.5 \pm 0.2 \mathrm{mmol} / \mathrm{l}$ in rats treated with antibody alone $\left(n=17\right.$ samples, $\left.\mathrm{F}_{2,51}=10.52, p<0.001\right)$. Immunohistochemistry revealed reduced Beta-cell granularity in four of the six pancreata that were free of insulitis in the antibody plus insulin group and in ten pancreata from rats treated with insulin alone.

In 110-day-old rats, the percentage of $\mathrm{RT}^{+}{ }^{+} \mathrm{ymph}$ node cells, which had been reduced during the course of anti-RT6 treatment to $1 \%(n=2)$ was found to have returned to higher levels $(40 \pm 1 \%, n=4)$. Up to 110 days of age only one of ten rats that had received insulin plus antiRT6.1 antibody between 30 and 60 days of age became diabetic, but thyroiditis and insulitis were both observed 
Table 1. Frequency of diabetes and insulitis in diabetes resistant (DR) rats treated with insulin, anti-RT6 monoclonal antibody, or both

\begin{tabular}{|c|c|c|c|c|c|c|}
\hline \multicolumn{2}{|c|}{ Experimental treatments and duration } & \multicolumn{2}{|c|}{ Outcome at 60 days of age } & \multicolumn{3}{|c|}{ Outcome at 110 days of age } \\
\hline Anti-RT6 & Insulin & Diabetic rats/total & Insulitis & Diabetic rats/total & Insulitis & Thyroiditis \\
\hline $30-60$ days & None & $16 / 20(80 \%)^{a}$ & - & $1 / 4(25 \%)^{\mathrm{c}}$ & $3 / 3(100 \%)^{d}$ & $2 / 3(67 \%)^{\mathrm{e}}$ \\
\hline $30-60$ days & $30-60$ days & $1 / 20(5 \%)$ & $3 / 9(33 \%)^{\mathrm{b}}$ & $1 / 10(10 \%)$ & $3 / 8(38 \%)$ & $6 / 7(86 \%)$ \\
\hline None & $30-60$ days & $0 / 17(0 \%)$ & $0 / 10(0 \%)$ & $0 / 7(0 \%)$ & $0 / 7(0 \%)$ & $0 / 7(0 \%)$ \\
\hline
\end{tabular}

All rats were injected and tested for diabetes up to 60 days of age. At 60 days of age a random sample of non-diabetic rats in the two groups that had received insulin was selected, killed, and studied histologically for the presence of insulitis. Because the number of rats in the antibodyalone group that had remained diabetic was small, it was elected not to kill them. All remaining non-diabetic rats were given no further injections and allowed to survive until diabetes onset or until 110 days of age at which time ail survivors were killed and studied for the presence of insulitis and thyroiditis. Plasma glucose concentration data for the three groups of treated rats during the period of injection are presented in the Results. Three animals in the insulin-alone group died during the first week of treatment and are excluded from the analysis. Statistical analyses were performed on each column in the table. ${ }^{a}$ Overall $\mathrm{chi}^{2}=37.17, \mathrm{df}=2, p<0.001 .{ }^{b}$ Fisher exact statistic $=0.09 .{ }^{\mathrm{c}} p=\mathrm{NS}{ }^{\mathrm{d}}$ Overall $\mathrm{chi}^{2}=9.56, \mathrm{df}=2, p<0.01 .{ }^{e}$ Overall $\mathrm{chi}^{2}=10.88, \mathrm{df}=2, p<0.005$

Table 2. Frequency of diabetes in adoptive recipients of mitogen-activated spleen cells from non-diabetic diabetes resistant (DR) $\mathrm{BB}$ rats treated with insulin, anti-RT6 mono clonal antibody, or both

\begin{tabular}{lcl}
\hline Treatment group & $\begin{array}{l}\text { Age at spleen cell harvest } \\
\text { (days) }\end{array}$ & $\begin{array}{l}\text { Diabetic rats/total } \\
(\%)\end{array}$ \\
\hline Anti-RT6 alone & 60 & $-\mathrm{a}$ \\
Insulin alone & 60 & $0 / 8(0 \%)$ \\
Anti-RT6 and insulin & 60 & $7 / 13(54 \%)$ \\
Anti-RT6 alone & 110 & $5 / 5(100 \%)^{\mathrm{b}}$ \\
Insulin alone & 110 & $0 / 6(0 \%)$ \\
Anti-RT6 and insulin & 110 & $6 / 8(67 \%)$ \\
\hline
\end{tabular}

Spleen cell donors were from among the non-diabetic rats described in Table 1. Adoptive recipients were 30 -day-old diabetes prone (DP) BB rats. Adoptive transfer in these animals was defined as the occurrence of diabetes before 60 days of age. The frequency of spontaneous diabetes among DP BB/Wor rats before 60 days of age was $<0.5 \%$ when these experiments were performed. DR donors were treated between 30 and 60 days of age only.

${ }^{a}$ All but four rats treated with anti-RT6 alone became diabetic; it was elected to allow all four to survive up to 110 days of age and their spleen cells were not tested until that time. Splenocytes from diabetic 60-day-old RT6-depleted rats transferred diabetes to eight of eight DP recipients.

b Overall chi ${ }^{2}=12.85, \mathrm{df}=2, p<0.002$ frequently (Table 1). One rat treated with anti-RT6 antibody alone became diabetic at 63 days of age, and of the three that remained non-diabetic up to 110 days of age, all had insulitis, thyroiditis, or both. No diabetes, insulitis or thyroiditis occurred in rats treated with insulin alone, and no residual decrease in Beta-cell granularity was found in their pancreata at 110 days of age.

Spleen cells from both 60- and 110-day-old nondiabetic DR rats treated with antibody and insulin adoptively transferred diabetes to naïve recipients (Table 2). The same was true of spleen cells from 110-day-old DR rats treated with antibody alone, but no DP recipients of spleen cells from rats treated with insulin alone became diabetic.

\section{Discussion}

The data provide answers to the three questions originally proposed. Insulin prophylaxis resulting in chronic hypoglycaemia does prevent diabetes in RT6-depleted DR $\mathrm{BB} /$ Wor rats, but it does not prevent lymphocytic thyroiditis or the development of spleen cell populations with the capability of adoptively transferring diabetes.

The prevention by insulin of autoimmune diabetes in RT6-depleted DR BB rats is consistent with previous observations made in the DP BB rat [1-3] and in the NOD mouse [4]. This protective effect was apparent not only during the period of RT6 ${ }^{+} \mathrm{T}$ cell depletion (up to 60 days of age), but also for many weeks after discontinuation of the insulin (up to 110 days of age). These observations suggest that insulin treatment did not simply delay the onset of disease in RT6-depleted DR rats, but rather that it interfered with an essential element of the diabetogenic process at an early stage. This "critical time period" interpretation is consistent with the previous observation that depletion of $\mathrm{RT}^{+}{ }^{+} \mathrm{T}$ cells does not induce diabetes in DR rats if treatment is begun at 60 days of age [8].

The data expand on previous reports by providing evidence of clinically inapparent pancreatic and thyroid autoreactivity in insulin-protected non-diabetic animals. We note first that insulitis and thyroiditis were present in many non-diabetic rats. Secondly, insulin treatment of RT6-depleted DR rats did not prevent the adoptive transfer of diabetes by their mitogen-activated spleen cells, suggesting the presence of autoreactive spleen cell populations in the absence of clinical diabetes. We interpret these observations to mean that insulin prophylaxis does not prevent the initiation of the autoimmune process in the RT6-treated DR rat. Rather, it interferes with some later stage of Beta-cell killing. This hypothesis is consistent with the observation of Woda and others in our laboratory that depletion of $\mathrm{CD}^{+}{ }^{+}$cells prevents diabetes but not insulitis in RT6-depleted DR rats [21]. Those data suggest that the $\mathrm{CD}^{+} \mathrm{T}$ cell subset may induce insulitis but, in the absence of $\mathrm{CD} 8^{+}$cells, it is not Beta-cell cytotoxic. 
That the differential effects of insulin we have observed on clinical vs subclinical islet autoimmunity could be mediated by differential effects on T cell subsets is an intriguing possibility deserving of further study.

The observation that spontaneous diabetes does not occur in insulin-treated RT6-depleted DR rats that nonetheless harbour spleen cells capable of the adoptive transfer of diabetes is an intriguing paradox. There are at least two ways to explain these findings. First, it could be that during the course of insulin treatment, populations of potentially autoreactive cells are regulated by an idiotypeantiidiotype mechanism. Upon in vitro stimulation with the mitogen concanavalin A, however, the effector cell population may escape idiotypic regulation. An alternative explanation is stoichiometric. Autoreactive cells in the insulin-treated animals may be present but too few in number to lead to the expression of spontaneous disease in the insulin-treated host. This interpretation is supported by the fact that insulitis is present in many of the non-diabetic insulin-treated animals. Successful adoptive transfer of diabetes using spleen cells from these animals may simply reflect mitogen-induced expansion of their numbers. This possibility is consistent with the observation that it is necessary to stimulate spleen cells with mitogen in order to achieve the adoptive transfer of both DP $\mathrm{BB}$ rat diabetes [10] and other autoimmune disorders such as experimental allergic encephalomyelitis [22].

The protective effect of insulin could be explained in many ways. Insulin-induced hypoglycaemia is known to reduce the stimulatory and trophic effects of glucose on Beta cells. Prolonged insulin-induced hypoglycaemia reduces Beta-cell mitotic activity and suppresses endogenous insulin production, secretion, and stores [23]. Such depression of Beta-cell metabolic activity with insulin renders them resistant to streptozotocin and alloxan $[24,25]$. The protective effect of insulin in Type 1 diabetes could be due to an analogous form of resistance to the Beta-cell cytotoxic effects of cytokines such as interleukin-1 released in the course of autoimmune processes [26].

Alteration of antigens that are targets of the autoimmune process could also occur in response to exogenous insulin. Beta-cell antigen expression is reportedly modified by manipulation of the glucose concentration in vitro $[27,28]$ and by the growth of insulin secreting tumours in vivo $[29,30]$. T cell clones reactive against a membrane component of the insulin secretory granule have been described [31], and reduction of insulin secretory activity could pari passu also reduce this form of Beta-cell antigenicity. Consistent with this hypothesis is the preliminary observation that diazoxide, an inhibitor of insulin secretion, also prevents diabetes in DP BB rats [32]. Decreased expression of islet cell antigens by insulin treatment may, in essence, conceal Beta cells from autoimmune-mediated destruction.

Alternatively, insulin treatment could affect the immune system directly. Immunization of young DP BB rats with insulin reportedly delays, but does not prevent diabetes [33]. Insulin is also an important regulator of growth and development and its receptors are found on most if not all macrophages, $T$ cells, and B cells [34]. A general inhibitory effect of insulin on the process that leads to autoimmunity is possible, but is not consistent with our observation that insulin treatment does not affect the incidence of thyroiditis.

This last result parallels observations that have been made on the effects of thyroxine [35] and methimazole [36] on thyroiditis in BB rats. Both of these agents reduce the incidence of thyroiditis without affecting the frequency of diabetes. Taken together, the parallel but nonoverlapping suppressive effects of insulin and thyroxine, and diazoxide and methimazole, all suggest that these agents provide target-specific protection.

In summary, our observations suggest that insulin treatment prevents the development of diabetes by an effect exerted at the level of the Beta-cell target, but a direct effect of insulin on the immune system cannot be excluded. Further studies to define the mechanism of action. of insulin treatment are important if we are to understand the appropriate role of exogenous insulin in the prophylaxis of human Type 1 diabetes.

Acknowledgements. We thank Ms. O. Treimanis, Ms. L.Paquin, and Ms. L. Leehy for assistance. This study was supported in part by grants DK 36024, DK 41235, DK 30657, and DK 36042 from the National Institutes of Health, and by a grant from the Juvenile Diabetes Foundation.

\section{References}

1. Gotfredsen CF, Buschard K, Frandsen EK (1985) Reduction of diabetes incidence of $\mathrm{BB}$ Wistar rats by early prophylactic insulin treatment of diabetes-prone animals. Diabetologia 28: 933-935

2. Appel MC, O'Neil JJ (1986) Prevention of spontaneous diabetes in the $\mathrm{BB} / \mathrm{W}$ rat by insulin treatment. Pancreas 1: 356 (Abstract)

3. Like AA, Weringer EJ (1989) Autoimmune diabetes in the BioBreeding/Worcester rat. In: Pipeleers D, Lefebvre P (eds) The pathology of the endocrine pancreas in diabetes. Springer, Berlin Heidelberg New York, pp 269-284

4. Atkinson MA, Maclaren NK, Luchetta R (1990) Insulitis and diabetes in NOD mice reduced by prophylactic insulin therapy. Diabetes 39: 933-937

5. Shah SC, Malone JI, Simpson NE (1989) A randomized trial of intensive insulin therapy in newly diagnosed insulin-dependent diabetes mellitus. N Engl J Med 320: 550-554

6. Keller JJ, Dumont Herskowitz R, Jackson RA (1990) Improvement in first phase insulin release in islet cell antibody (ICA) positive relatives treated with insulin. Diabetes 39 [Suppl 1]: 103A (Abstract)

7. Butler L, Guberski DL, Like AA (1988) Genetics of diabetes production in the Worcester colony of the BB rat. In: Shafrir E, Renold AE (eds) Frontiers in diabetes research. Lessons from animal diabetes II. Libbey, London, pp 74-78

8. Greiner DL, Mordes JP, Handler ES, Angelillo M, Nakamura N, Rossini AA (1987) Depletion of RT6.1 + T lymphocytes induces diabetes in resistant BioBreeding/Worcester (BB/W) rats. J Exp Med 166: 461-475

9. Ely JM, Greiner DL, Lubaroff DM, Fitch FW (1983) Characterization of monoclonal antibodies that define rat $\mathrm{T}$ cell alioantigens. J Immunol 130: 2798-2803

10. McKeever U, Mordes JP, Greiner DL, Appel MC, Rozing J, Handler ES, Rossini AA (1990) Adoptive transfer of autoimmune diabetes and thyroiditis to athymic rats. Proc Natl Acad Sci USA 87: 7718-7722

11. Guberski DL, Butler L, Like AA (1990) Environmental viral agents influence spontaneous and RT6 depletion induced diabetes in the BB/Wor rat. Diabetes 39 [Suppl 1]: 97A (Abstract) 
12. Thomas VA, Woda BA, Handler ES, Greiner DL, Mordes JP, Rossini AA (1991) Altered expression of diabetes in BB/Wor rats by exposure to viral pathogens. Diabetes 40: 253--258

13. Greiner DL, Handler ES, Nakano K, Mordes JP, Rossini AA (1986) Absence of the RT-6 T cell subset in diabetes-prone BB/W rats. J Immunol 136: 148-151

14. National Institutes of Health (1985) Guide for the care and use of laboratory animais. Department of Health, Education and Welfare Publication NIH 78-23. DHEW, Washington, DC

15. Woda BA, Padden C, McFadden ML (1988) T helper $\left(\mathrm{T}_{\mathrm{H}}\right)$ cells in the BioBreeding Worcester (BB/Wor) rat are subdivided into distinct subpopulations by the OX22 and RT6 antibodies. Diabetes 37 [Suppl 1]: 205A (Abstract)

16. Milford EL, Paradyse JM, Carpenter CB (1983) A monoclonal alloantibody that detects HLA-B7-associated polymorphism. Transplant Proc 15: 1974-1975

17. Koevary S, Rossini AA, Stoller W, Chick W, Williams RM (1983) Passive transfer of diabetes in the $\mathrm{BB} / \mathrm{W}$ rat. Science 220 : 727-728

18. Like AA, Appel MC, Williams RM, Rossini AA (1978) Streptozotocin-induced pancreatic insulitis in mice. Morphologic and physiologic studies. Lab Invest 38: 470-486

19. Nie NH, Hull CH, Jenkins JG, Steinbrenner K, Bent DH (1975) Statistical package for the social sciences, 2 nd edn. McGraw-Hill, New York

20. Siegel S (1956) Nonparametric statistics. McGraw-Hill, New York

21. Woda BA, Handler ES, Greiner DL, Reynolds C, Mordes JP, Rossini AA (in press) $T$ cells are required for diabetes in the RT6-depleted diabetes resistant BB rat. Diabetes (in press)

22. Panitch HS, McFarlin DE (1977) Experimental allergic encephalomyelitis: enhancement of cell-mediated transfer by concanavalin A. J Immunol 119: 1134-1137

23. Chick WL, Warren S, Chute RN, Like AA, Lauris V, Kitchen KC (1980) A transplantable insulinoma in the rat. Proc Natl Acad Sci USA 74: 628-632

24. Appel MC, Thompson MJ, Rossini AA, Like AA (1982) Islet Bcell functional activity affects susceptibility to injury. Diabetes 31 [Suppl 2]: 146A (Abstract)

25. Portha B, Picon L (1982) Insulin treatment improves the spontaneous remission of neonatal streptozotocin diabetes in the rat. Diabetes 31: 165-169

26. Nerup J, Mandrup-Poulsen T, Mølvig J, Helqvist S, Wogensen L, Egeberg J (1988) Mechanisms of pancreatic $\beta$-cell destruction in Type I diabetes. Diab Care 11 [Suppl 1]: 16-23
27. Aaen K, Rygaard J, Josefsen K, Petersen H, Brogren C-H, Horn $T$, Buschard K (1990) Dependence of antigen expression on functional state of $\beta$-cells. Diabetes 39: 697-701

28. Kämpe O, Andersson A, Björk E, Hallberg A, Karlsson FA (1989) High-glucose stimulation of $64,000-M_{\mathrm{r}}$ islet cell autoantigen expression. Diabetes 38: 1326-1328

29. Appel MC, Dotta F, O'Neil JJ, Eisenbarth GS (1989) B-cell activity regulates the expression of islet antigenic determinants. Diabetologia 32: 461 (Abstract)

30. Dotta F, Ziegler R, O'Neil JJ, Nayak RC, Eisenbarth GS (1989) Islet autoimmunity: identification and initial characterization of a metabolically regulable pancreatic ganglioside. Diabetologia 32: 483 (Abstract)

31. Roep BO, Arden SD, DeVries RRP, Hutton JC (1990) T-cell clones from a Type-1 diabetes patient respond to insulin secretory granule proteins. Nature 345: 632-634

32. Vlahos WD, Yale J-F (1987) Prevention of Type I diabetes in the $\mathrm{BB}$ rat by diazoxide. Clin Invest Med 10: B65

33. Klöting I, Sadewasser S, Lucke S, Vogt L, Hahn HJ (1988) Development of BB rat diabetes is delayed or prevented by infections or applications of immunogens. In: Shafrir E, Renold AE (eds) Frontiers in diabetes research. Lessons from animal diabetes II. Libbey, London, pp 190-194

34. Heldermann JH, Strom TB (1976) Emergence of insulin receptors upon alloimmune T cells in the rat. J Clin Invest 59: 338-344

35. Reinhardt W, Paul TL, Allen EM, Alex S, Yang Y-N, Appel MC, Braverman LE (1988) Effect of L-thyroxine administration on the incidence of iodine-induced and spontaneous lymphocytic thyroiditis in the BB/Wor rat. Endocrinology 122: 1179-1181

36. Reinhardt W, Appel MC, Alex S, Yang Y-N, Bravermann LE (1989) The inhibitory effect of large doses of methimazole on iodine-induced lymphocytic thyroiditis and serum anti-thyroglobulin antibody titers in BB/Wor rats. J Endocrinol Invest 12 : $559-563$

Received: 17 September 1990

and in revised form: 23 November 1990

A.A. Rossini, M.D.

Diabetes Division

University of Massachusetts Medical Center

55 Lake Avenue North

Worcester, MA 01655

USA 